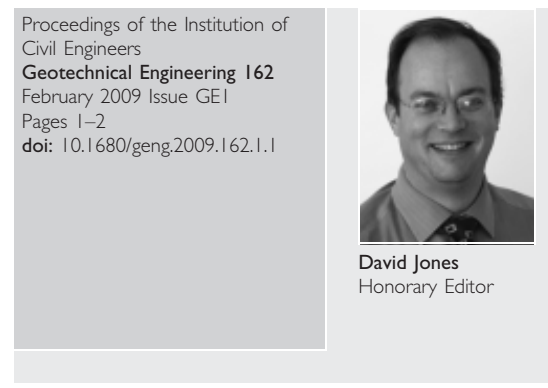

\title{
Editorial
}

D. Jones BSc, MSc, CEng, MICE, MIMMM, FGS

As new Honorary Editor I am pleased to welcome you to the first issue of Geotechnical Engineering in 2009.

Thanks are due to my predecessor, Tim Fitch who initiated a number of developments during his tenure; in the October 2008 issue he expressed thanks to three members of the Panel standing down. I am pleased to welcome six new members of the Panel: Michael Brown from the University of Dundee, Stephen Fort of High-Point Rendel, Peter Ingram of Arup, Shon Williams of STATS Ltd, Adam Pellew of RKD Consultant Ltd and Chris Pound of Mott MacDonald.

The increased Editorial Advisory Panel membership is drawn from client companies, contractors, consultants and academia and along with the increased engagement of the 12 international members I believe that the panel is well structured to support and consolidate the continuation of six editions annually. Fundamentally the success of the journal will continue if the flow of high quality papers is maintained and I invite submissions as outlined under 'Aims and Scope'. Additionally, over the next three years I envisage that we shall continue the popular and succesful series of themed issues, we will include reviews of books likely to be of interest to the readership and, as always, we encourage written discussion of recently published papers.

With the increase in journal issues and maintenance of a healthy flow of submitted papers we have a responsibility to give prospective authors the expectation that review time prior to a decision will be as efficient as possible. I feel the subcommittee structure, efforts of the Editorial Coordinator and continued application of the online Editorial Management system provide an opportunity to reduce the time to editorial decision.

Despite the prevailing global economic challenges there are a number of large and challenging geotechnical projects planned or ongoing in the UK. These will provide the opportunity for papers to demonstrate, inter alia, the high quality of geotechnical engineering, innovation and succesful implementation of collaborative ventures in our industry. Publication provides a showcase for this expertise and shares knowledge across the geotechnical community. Over the next three years, in addition to significant projects and programmes, European Design and Execution Standards will have an increasing influence upon geotechnical design and construction and it would be anticipated that this will be reflected in a number of future papers.

With this issue you will find a call for papers for our first themed issue of 2010 concentrating on Geotechnical Engineering related to Tunnelling; the themed issue Subcommittee Chairman for that issue is Brian McGinnity.

This year we commence with a themed issue Coastal stabilisation and near-shore geotechnical engineering. Subcommittee Chairman Philip Smith provides an introduction to the issue and topics below.

The move to six issues a year results in the first edition moving from January to Febuary, nonetheless I trust you will allow me to wish you all a happy and productive 2009.

\section{Philip Smith}

This edition of Geotechnical Engineering is one of the ongoing series of themed issues which focus on particular areas of interest to the profession. The call for papers for this themed issue (which is titled Coastal stabilisation and near-shore geotechnical engineering) requested papers on six main topics, namely

- case histories of cliff stabilisation

- geotechnical aspects of ports, docks and other marine infrastructure

- advances in marine site investigation

- effects of climate change on coastal slope management

- embankments for marine flood protection

- current research in near-shore geotechnical engineering.

The papers presented in this special publication are diverse and cover a wide range of subject matter from around the world. They describe matters such as innovative breakwater construction in the Yangtze Estuary, the difficulties associated with land reclamation on top of large thicknesses of soft clay in Singapore, simple but robust ground investigation techniques for use in Aceh Province following the Tsunami of December 2004, techniques for cliff stabilisation in the UK and the innovative use of biogrout to stabilise coastal dunes in the Netherlands.

A common theme throughout these papers is the need to find innovative solutions or innovative combinations of solutions to 
the difficult problems that are frequently encountered at the land-water interface and where issues such as wave climate during construction, coastal erosion and massive postconstruction settlements further complicate an already complex design process.
Many of the papers presented also reflect on the difficulties of engineering in coastal regions which are often part of fragile eco-systems. Issues such as adaptation, the impact of climate change and the need for environmental sensitivity often underscore the main engineering theme. 